\title{
Article
}

\section{Sport hunting and tourism in the twenty- second century: humans as the ultimate trophy}

\author{
Wright, Daniel \\ Available at http://clok.uclan.ac.uk/28755/ \\ Wright, Daniel ORCID: 0000-0001-9976-5799 (2019) Sport hunting and \\ tourism in the twenty-second century: humans as the ultimate trophy. \\ Foresight, 21 (3). pp. 419-442. ISSN 1463-6689
}

It is advisable to refer to the publisher's version if you intend to cite from the work. http://dx.doi.org/10.1108/FS-11-2018-0092

For more information about UCLan's research in this area go to http://www.uclan.ac.uk/researchgroups/ and search for < name of research Group>.

For information about Research generally at UCLan please go to http://www.uclan.ac.uk/research/

All outputs in CLoK are protected by Intellectual Property Rights law, including Copyright law. Copyright, IPR and Moral Rights for the works on this site are retained by the individual authors and/or other copyright owners. Terms and conditions for use of this material are defined in the policies page. 


\section{Title: Sport hunting and tourism in the $22^{\text {nd }}$ Century: Humans as the ultimate trophy}

\section{Introduction}

Is sport beneficial or harmful for society and its members? (Wann, Melnick, Russell, Pease, 2001: 1).

What will be the future role of sport within a travel and tourism context? Could it consist of an environment where there is a potential shift in hunting animals for sport to hunting humans for sport? This idea is explored in this paper. Academic researchers, industry professionals, authors and futurologist aim to provide visions, a lens spearing towards a time and place in the future. Future visions, presented as scenarios can be comprised of narratives, a short story. The scenario or short story provides a written account of what the future might look like, it offers the reader a vividly written interpretation of the future, making the future scenario more interpretable, imaginable. Importantly, the scenario should be justified, there should be evidence that supports the ideas being presented. The evidence used to justify the future scenario is taken from real entities, tangible and nontangible, such as social and scientific knowledge, ideas, beliefs, entities that we can see and understand from our past and current world. Through the exploration of past and current society trends researchers are able to understand and justify what is driving humanity into potential future realities. Exploring the future is of great significance. It aims to ensure the safeguarding of humanity, society, our natural environment, and for business and organisations it offers a template to consider potential product and service developments, changes, growth and new market opportunities, consumer purchasing patterns and much more. Researching what the future might entail, what it might look like, people, the environment and how organisations might operate, is arguably essential in order to maintain and understand where we are heading as a collective species. Significantly, are we content with the evolutionary progression society is potentially establishing? After all, what we do now has the ability to affect the future in all manner of forms. The future has the potential to exist as a result of what society is doing today. Thus, it is suggested that exploring current trends as a means to explore the future is highly relevant and justifiable.

In a recent publication, Hunting humans: $A$ future for tourism in 2200, the author, Wright (2016) explores how in the year 2200 hunting humans could potentially be a practice carried out by the wealthy-elite. The scenario depicts a somewhat dystopian future, at least it seems like one from our perspective. As the author notes, if the scenario become real, in the future it may not be a dystopian world for the people who exist, it will just be their reality. An analysis of past and current trends are explored as means of justifying the potential future. A focal aspect of this scenario in line with tourism is the concept and progressive nature of entertainment and theme parks. The author suggests that in the year 2200 tourism and hunting humans could form part of the tourism entertainment industry. In the scenario Wright (2016) briefly narrates, what the future might be like in the year 2100 , a somewhat mid-way point, between now and the year 2200 (2200 being Wright's scenario). The following is an extract from Wright's (2016: 38) scenario:

"The secret and dirty world of tourism in the past (2100) involved the mega-rich (a small percentage of the wealthy-elite) partaking in the hunting humans activity. During these activities the oppressive mega-rich carried out vacations to purposely slaughter humans, with the 'claimed' aim to reduce population size, but an element of perverse thrill and excitement was said to be fuelling the demand" (Wright, 2016: 38). 
It is at this moment in time, the year 2100 that this research will focus on. However, in the scenario offered by Wright (2016), a key element was somewhat overlooked, the role of sport. Sport has long been a pastime and an activity that has played a vital role throughout time and across societies. However, for the scenario of hunting humans to become a reality, this paper will explore and ultimately argue that the concept of sport, its role and its meaning as a social activity will act as a driver for the potential of hunting humans in the future to become a more commonly associated (sport) tourism activity. Hunting humans has been considered in previous research and in past fictional and movie narratives, some of which are considered in this paper. Importantly, this does not weaken the originality to this research, somewhat the contrary. What this research offers is a continued but novel exploration of a discussion that could become a reality in the future, one that has been considered in the past and will likely be considered in the future. Just because an area has been explored in the past, does not mean that it should not be further explored over time. In fact, the representativeness of topics in previous research, arguably adds credit and value to explore further. This is emphasised in this case, where the potential reality of a future where humans hunt humans for sport is further explored, from contemporary perspectives adding original discussions and evidence as supporting evidence.

It is significant to note that scenario planning and written narratives are rarely used as a method of research, and an approach that has limited coverage and application in the field of sport tourism research. Thus, before offering a scenario for the reader, it is necessary to justify the research method before exploring the historical developments of sport and more specifically sport hunting as central themes to the research. This will be followed by a critical exploration of the trend analysis approach used to justify this research and the scenario presented.

The future of society is of boundless examination, it is an open-ended question - so let us begin asking the right questions.

\section{Research epistemology method and approach}

The application of scenario planning to the wider literature of sport tourism is a somewhat novel approach. The conventional practices of research epistemologies and methodologies are not commonly applied, and arguably, rightly so. As predicting the future and offering a scenario of what the future might look like, requires alternative methods of researching, writing and presentation of data, analysis and findings. Consequently, this paper for some will be provocative and contested; whilst for others it will be welcomed and original. By provocation, this paper could arguably encourage its readers to move beyond their normal patterns of thinking. It is suggested, that we seldomly venture beyond our established knowledge, based on past experiences and the logical extension of those experiences. Thus, to provoke an idea could unsettle the mind of the reader, consequently, increasing the potential that the audience will generate new ideas (de Bono, 1995) potentially, even new behaviours. It is stressed that the application of scenario methodologies opens up a new field of research for the sport tourism field and one that should be accepted and explored further to understand its benefits for industry and academic purposes, thus, offering original research to the sport tourism literature.

Planning for the future is necessary and common practice for business, organizations, nation states, developers, collectives, individuals and generally people with an interest in looking forward into the near or distant future, and a scenario approach to present plausible and genuine future realities are commonly applied within tourism (see Journal of Tourism Futures). Ramirez, Mukherjee, Vezzoli and Kramer (2015) identify that the term and application of 'scenarios' varies across subject fields and practices. Various scholars have used different 
terms in relation to scenarios, such as scenario thinking used by Han (2011) who suggested that when researching international relations, the application of scenario thinking offered a complementary toolkit, generating new ideas, arguments, and broadening the range of casual relationships that are studied. 'Scenario analysis' was applied by Sankaran, Dick, Shaw, and Cartwright (2014) to research leadership, whilst Ravera, Hubacek, Reed, and Tarrason (2011) used 'scenario development'. However, to date the most commonly used and applied approach associated with scenarios, is planning (Zenter, 1982; Godet \& Roubelat, 1996; Godet, 2000; Chermack, Lynham \& Ruona, 2001; van der Heijden, 2005; Ringland, 2006; Roxburgh, 2009; Chermack, 2011). Research focused on exploring and presenting potential future realities are commonly associated with the use and application of scenario planning as a methodology. Many authors have offered definitions, for example Heijden, Bradfield, Burt, Cairns, \& Wright (2002) suggest that "scenario planning is a process of predicting multiple, plausible and uncertain futures". For some "scenarios are understood to be a small bespoke set of structured conceptual systems of equally plausible future context, often presented as narrative descriptions, manufactured for someone and for a purpose..." (Ramirez et al., 2015: 71). Thus, a commonly used method of exploring the future in accordance to scenario planning, is to present a story, one with narratives (Lindgren \& Bandhold, 2009), offering a setting, a time frame, and additional details commonly associated with storytelling, allowing an audience to further engage and visually explore the ideas being presented. As discussed by Schwartz (1991: 4) scenarios can be used as a 'tool for ordering one's perceptions about alternative future environments in which one's decisions might be played out. Alternatively: a set of organised ways for us to dream effectively about our own future". Concretely, scenarios bear a resemblance to a set of stories; written out or spoken. Scenario "stories are built around carefully constructed "plots" that make the significant elements of the world scene stand out boldly" (Schwartz, 1991: 4). And Schwartz notes that this approach is more a disciplined way of thinking than formal and commonly applied methodologies.

As proposed by Ramirez, et al., (2015: 82) "scenarios have moved on from an object of research by scholars into a research methodology scholars now use to produce "interesting research", manifesting epistemological issues that the broader futures field has grappled with". "Interesting research" refers to authors' adopting methodologies that stimulate and challenge new ideas (Alvesson \& Sandberg, 2011; Ramirez, et al., 2015). Research that is more interesting in the sense that it is more likely to produce learning, to be read, understood, debated, remembered (Bartunek, Rynes, \& Ireland, 2006), and to attract a wider audience beyond the field of study; the original contexts and audience it was written for. According to Larson (2002), in considering alternate paths into the future, it is evident that negative and positive scenarios are often not symmetric to each other, and Larson (2002: 7) suggests that negative scenarios are often easier to formulate. Suggesting that, it is more simplistic to "extrapolate trends such as population growth and resource depletion and describe scenarios in which the world is moving toward disorder and crisis."

To present future predictions, it is suggested that researchers should consider the past and the present. To establish a historical understanding of humanity as the past is forever embedded in our current existence (Wilkins, 2013). Predicting the future is defined as the forecasting of the future on a systematic basis by studying current day trends in human affairs (The Oxford English Dictionary, 2015). Thus, acknowledging and justifying the future should include the analysis of past and current "trends" (Wright, 2016). This method is widely used, for example in Friedman (2009) suggests, "I have no crystal ball. I do, however, have a method that has served me well, imperfect though it might be, in understanding the past and anticipating the future. Underneath the disorder of history, my task is to try to see the orderand to anticipate what events, trends and technology that order will bring forth."

It is argued that a holistic and all-encompassing approach to research the future is necessary. It is necessary because, our world is incredibly complex to understand, and if we are to offer future predictions, to which there are an infinite number of possibilities (Peterson, Cumming, 
\& Carpenter, 2003) considering the past and present in order to contemplate the future is seen favourably. Thus, researchers should not limit their capabilities to explore the future, and should, through the application of multiple research epistemologies and methodologies have a stronger ability to offer a more valid judgment, and thus future scenario (Wright, 2016). Like other approaches within the field of futures study (such as Yeoman, 2012; Postma, 2015; Wright, 2016) this research explores the commonly recognized areas driving the future, the natural environment and social developments. Sub-themes are also explored in accordance to the thematic topics that are evaluated in line with the future scenario, which will be explored in detail shortly. For the impending scenario, the researcher explored and analysed secondary data sources, of both qualitative and quantitative forms, from past and current knowledge, ideas, beliefs and attitudes, from a multitude of academic and industry perspectives. Thus, the epistemological approach taken in this research is holistic by nature and embracing of different views from the secondary data recourses examined, from constructivism to positivism. Thus, aiming to provide a more balanced and distinct future scenario.

\section{Hunting since the dawn of time}

The word hunt (noun) and hunting (verb) refers to the pursuit and killing of wild game for sport or food, and or the search for someone or something and also includes the associated act: "to be on a hunt" (Oxford Dictionaries, 2017a). Hunting is a practice whose roots can be located back to pre Homo sapiens (Gaudzinski, 2004; Rabinovich, Gaudzinski-Windheuser, \& GorenInbar, 2008), and evidence from research conducted by Wong (2014) in a paper entitled, "how hunting made us human", suggests that hunting has taken place for more than 2 million years. Early hunting practices lent themselves more to the subsistence elements, such as survival and maintenance (food and control). Hunting was seen as a central element of hunter-gatherer societies (beginning about 11,000 years ago) before the domestication of livestock and the emergence of agriculture and evidence puts the earliest known mammoth hunting in Asia, with spears, to approximately 16,200 years ago (Zenin, Mashenko, Leshchinskiy, Pavlov, Grootes, \& Nadeau, 2003). Some tribal communities have (or at least until recently) and continue to preserve paleolithic hunting-gathering, such as indigenous peoples of the Amazonas (Aché), Central and Southern African tribes (San peole), peoples of New Guinea (Fayu), the Mlabri of Thailand and Laos, and the Vedda people of Sri Lanka. Moreover, there is a likelihood that uncontacted tribes continue hunting practices (Lindsay, 2009; Encyclopedia Britannica, 2017). Hunting is a phenomenon that is practiced around the globe and a mixture of personal motives drives its participants. The activity of hunting is reported in all inhabited regions of the world and is often described and associated as a means to source food for inhabitants of rural areas (Nasi, Taber, and van Vliet, 2011). The consumption of bushmeat by local populations is recognized as a key source to obtaining protein (Redford 1992). Human population growth, the increased accessibility of remote areas, and improvement in hunting techniques in the last decades have resulted in a remarkable intensification of the harvest rate of wild animals for consumption and trade (Fa and Yuste, 2001; Nasi, Brown, Wilkie, Bennett, Tutin, van Tol, and Christophersen, 2008).

This research will not delve deeply into the practices of hunting for food. Interestingly for this study is the dynamic shift of hunting, one from a more subsistence activity to a social one. In line with this, two important trends gradually emerged. First, being the advancement of the specialist hunter, as training and equipment developed, and secondly, the growth of cooperation in hunting as a "sport", often associated and seen as an upper class activity (Machiavelli, 1531: 519). Manning (1993) notes that poaching, or unlawful hunting, was a persistent phenomenon and dates back to the Anglo-Norman age when feudal monarchs endeavoured to proclaim exclusive hunting rights over vast game reserves designated as royal forests and chases. Manning (1993) suggests that hunting was an integral element of aristocratic culture, a well-regarded and time-consuming activity. Hunting, both lawfully and 
unlawfully obtained a sense of aura, of danger and adventure and offered the younger gentleman an opportunity to cut a self-image of displaying and overcoming difficult feats, offering daring displays of courage. According to Moryson (1617), in reference to hunting, "no nation so frequently useth these sports as the English". Burton (1621) pronounced hunting as "the sole almost and ordinary sport of all our noblemen,... tis all their study, their existence, ordinary business, all their talk, and indeed some dote too much on it; they can do nothing else, discourse of nought else" (Henricks, 1991: 118). Petit-Dutaillis (1914:211) delivered the following, "We need only recall how great a part was played by the chase in the life of a medieval man. It was the favourite sport of the nobles; in time of peace it offered a substitute for war..." A common subject for writers in the Renaissance period was the notion that hunting was used as rehearsal for war, because the 'ancient' societies, specifically kings and warriors, often commended and pursued hunting as a pastime. Thus, hunting was an opportunity to prepare for war, and was seen as a symbolic substitute for war in England during periods when full-scale combat was limited (Manning, 1993). Hunting is not new and sport hunting likewise is not a novel activity, it, like many sports has over time and space developed, evolved and impacted wider territories, and continues to be a practice of attaining food and as a sporting leisure activity.

\section{Sport tourism and hunting}

Sports are timeless, yet with each generation, new technology and social dynamics have changed and intensified how we experience sports...

...The changes on the horizon will likely be even more disruptive" (Jacobs, 2015).

"Sports are elements of culture, and they have forms and meanings, which vary over time and from one group and society to the next" (Coakley \& Pike, 2009: 4). As such, the meaning of sport varies across time and space and evolves over time across societies. Importantly, what constitutes a sport to one culture might not to another. The nature of sport tourism is suggested to be "... a cultural experience of physical activity tied to a cultural experience of place" (Standeven and De Knop, 1999: 62). According to Eric Dunning (1999), "sport matters," moreover, sport is seen as an "important identity-prop... a site where significant battles over gender identities and gender roles are... fought," and sport allows people to establish an identification of self, to identify themselves within a group, a sense of belonging, it shapes the conception of self and provides ranking of individuals in the group (Dunning, 1999, 5-6; Dunning, 1986). Societies are a mixture of 'unique ethos', 'subcultures' and sport hunting has long been a human activity, with its participants and application varied across time and societies. The question, is hunting a sport, has been explored by authors such as Coakley \& Pike (2009). The author suggests that some forms of sport, such as hunting could be perceived as deviant leisure (if the reader is interested in exploring more of these debates see Coakley \& Pike). Interestingly, it is suggested that the roots of many modern forms of sport can be traced to hunting activities. According to Elias \& Dunning (1986) fox-hunting was of the first activities where the 'term' sport was attached. An example where hunting was recognised as a sport was the 1900 Paris Olympic Games where the live pigeon-shooting event was won by Belgian athlete, Leon de Lunden, who killed 21 birds on his way to victory (Coakley \& Pike, 2009). This paper will not concern itself with the debate is hunting a sport, see Coakley and Pike (2009) for more on this. Instead the following suggesting is sufficient, "hunting is a controversial sport which is supported by many but described by others as cruel and deviant" (source: Elizabeth Pike, see Coakley and Pike, 2009: 207).

"The Thrill of the Hunt - What's the appeal of squeezing off a few rounds into a defenseless animal? We commie liberals may never understand, but that didn't stop me from heading into the woods with my right-wing-nutcase friend" (Cartwright, 2005: 88). 
Travel for leisure and sport is not a new activity, however, attention on sport tourism has seen significant growth from industries and academics throughout the past few decades, since the mid-1990s (Standeven \& De Knop, 1999; Weed, 1998; Weed \& Bull, 2009; Hinch \& Higham, 2011). The definition of sport tourism can be as simple as "...the use of sports for tourism endeavours" (Kurtzman, 1995:1). A more complex definition could be considered as "all forms of active and passive involvement in sporting activity, participated in casually or in an organised way for noncommercial or business/commercial reasons, that necessitates travel away from home and work locality" (Standeven \& De Knop, 1999: 12). Similarly, Hinch and Higham (2001: 29) offer this definition, "...sport-based travel away from the home environment for a limited time where sport is characterised by unique rule sets, competition related to physical prowess and a playful nature". Other definitions focus on motivational and experiential features of sport tourism (Nogowa et al., 1996; Gammon \& Robinson, 1997), whilst other definitions such as Weed and Bull (1997) focus on the social, cultural and economic implications that the composite of sport and tourism can generate (Gammon, 2015).

The meaning of sport tourism could be said to include three elements, an active type and a passive form (Hall, 1992) and that concerned with nostalgia (Redmond, 1991). From these three elements, Gibson (2006: 2) offers a definition of sport tourism as "leisure based travel that takes individuals temporarily outside of their home communities to participate in physical activities [Active Sport Tourism], to watch physical activities [Event Sport Tourism], or to venerate attractions associated with physical activities [Nostalgic Sport Tourism]." The first aspect of this definition, the participatory engagement of sport tourism is the focus of this research. Participatory literature has included scholarly works of Standeven \& De Knop (1999) offering classificatory systems, Gammon \& Robinson (1997) offered early typologies of sport tourism, and the active and passive forms of sport tourism as an activity and classifications were offered by Hall (1992) and Gibson (1998). Additionally, participants can be classified as undertaking sport tourism in competitive (hard definition) or recreational (soft definition) contexts (Jones \& Green, 2006). However, tourist typologies have their weaknesses, and such is the rarity that one can assign participants into idea-type categories and typologies, and the over simplified nature of them in appreciation to the complexity of human nature is somewhat overlooked (Gibson, 2006). Furthermore, Gibson (2006) suggests that the focus is on the examination and understanding of the (sport tourism related) activity rather than identifying with the meaning, norms and values of the individuals and collectives undertaking the activity. In the wider context and meaning of tourism and leisure, and in line with the participants' norms and values, especially from a hunting perspective, Jones \& Green's (2006) subcultural, social world, and the unique ethos of serious leisure are of interest to this research. For further discussions on 'serious' leisure see Jones \& Green (2006: 32-48). Geographical segmentation of the active sport tourism market is also of popular discussion in literature (Hinch \& Higham, 2011). Here focus can be on the visitor origins, where the tourist comes from (the generating region) and the market location where the activity takes place. This is significant, as different geographical locations allow for different types of sporting activity to occur, some locations offering suitable terrain, weather conditions, and or natural and built environments for varying sporting purposes (Bale, 1989; Rooney \& Pillsbury, 1992).

This research considers the importance of identity in active sport participation. The term 'unique ethos' according to Yinger (1960) is the "conceptualization of a subculture as a normative system used to set a group apart from a larger whole" (Jones \& Green, 2006: 40). Thus, sports and leisure activities exist in their own independent social world and the participants of the different (sport and leisure) activities represent a distinct segment within those social worlds. In doing so, they would be adherent to a set of norms, values and behaviours that differentiate them to the wider social environment. Then, within these participatory social worlds, there are different forms and levels of involvement (Jones \& Green, 2006). In line with hunting, there exists a social world that is not always recognisable and understandable to the wider collective community. A subcultural (or deviant) world that exists, an identity and a sport that individuals (participants) align themselves to, taking on shared 
symbols, ideologies, values and behaviours, some of which are potentially seen unfavourably by the wider social world, but it does not mean they do not exist. Sport hunting and tourism could be seen as one of these social worlds.

Various governments and tourism organisations have implemented strategies to support and promote activities of sport tourism and those related to hunting. Unlike subsistence hunting, the motivations for practicing in sport hunting are guided primarily by the thrill of chasing and killing animals (Loveridge, Reynolds, and Milner-Gulland, 2006). Because of its cultural features that are not linked to the need for food, sport hunting provokes divided opinions among conservationists. Hunting tourism advanced over time in line with imperial expansion, as adventurers left Europe and ventured to new pastures, the fashion of collecting trophies was popular, as it was used as a 'proof' of far of places they had visited and to the confronts with strange animals encountered on their journeys (Petroman, et al., 2015). More contemporary and modern practices of trophy hunting are less associated with actual physical animal body parts, (at least for the amateur hunter) for many purposes, such as international border crossing regulations. Today, trophies are more in the form of photographic evidence (Petroman, et al., 2015), a famous example being an image of Queen Elizabeth and Prince Philip pictured with local rulers after a tiger shoot in the Indian region of Jaipur in 1961 (Batchelor, 2015). Petroman et al., (2015) taking an economic and social perspective suggest that hunting tourism can be viewed from two sub-categories. Firstly, 'resident hunting, hunting for food and secondly, 'tourism hunting', associated with travellers who travel to participate in hunting activates. Petroman et al., (2015) go on to suggest that tourism hunting can be categorized into six types of tourism: 1) subsistence indigenous hunting, 2) traditional hunting, 3) commercial hunting, 4) recreational-sport hunting, 5) integrated hunting, and 6) optimum level game maintenance hunting. From this the authors suggest that hunting tourists can be classified into three distinct categories:

1. Large game hunting tourists (for whom what matters is adventure and trophies),

2. Small game hunting tourists (interested in the hunting experience), and

3. Experienced hunting tourists (characterised by the use of frontal charge guns or arrow shooting).

Additionally, hunting tourism can also be considered as a sub-category in the following areas: Nature tourism because it has the potential to act as a preservation technique in control and management of areas of biodiversity; sustainable tourism in protected areas (ecotourism); cultural tourism due to its educational components as a cultural activity; and hunting tourism can be a sub-category to trophy hunting (Petroman, et al., 2015), which have been considered and presented by the authors in a 'place of hunting spectrum, presented in figure 1. 
Figure 1. Place of hunting tourism - categories of consumption

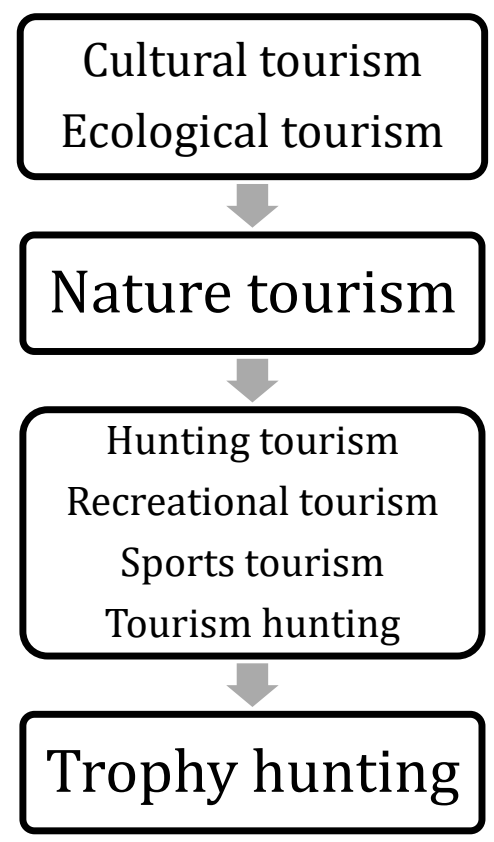

(Source: Adapted from Petroman, et al., 2015: 200)

In Africa, programs for sport hunting of wildlife were developed in 23 countries as a strategy for generating income for rural communities (Lindsey, Frank, Alexander, Mathieson and Romanach, (2007). In most cases, hunters are foreign tourists from Europe and the United States, some of which become sensational media stories, a recent example being the hunting and killing of Zimbabwe's Cecil the Lion by Walter Palmer, an American dentist, who later expressed his regret (ABC News, 2015). Obtaining trophies such as skulls, horns and teeth, collected by hunters is also seen as another common type of sport hunting in North America (El Bizri, et al., 2015). As noted, it is a historical and current leisure / tourist activity with a diverse participatory market. In the case of Walter Palmer a recent article discussed how sport hunting is not uncommon in society. In this example, Safari Club International (SCI), who identify themselves as: The Ultimate Sportsman's Market, boast a club membership of 55,000, and as they state:

"Safari Club International is the leading voice in the fight to protect our freedom to hunt, both in the United States and internationally. The SCl Hunter Advocacy department is headquartered in Washington, DC, advocating on behalf of SCI members and non-members alike. From staff dedicated to legislation and policy to a team of litigators, SCI Hunter Advocacy is at the forefront of protecting our hunting heritage" (SCI, 2016).

According to Steinbuch (2015) Walter Palmer, as a member of SCI, has 43 bow-and-arrow kills - including a polar bear, buffalo and mountain lion. The club retains a comprehensive record of its 55,000 members', which include photos and information on the animals they have killed. Apparently, Palmer has racked up points and prizes for his kills, and is part of two-dozen hunters who have achieved what is called the North American Super Slam. To achieve this one must hunt and kill all 29 big-game animals (Steinbuch, 2015). Trophy hunting and the thrill that comes with it, take shape in many forms across the tourism landscape, from professional hunting and gaming to wild acts of animal savagery. The more experienced trophy hunters are often motivated by competitions sponsored by trophy hunting organizations such as the $\mathrm{SCl}$, who give hunting awards, many different categories of awards exist, including: 
- The Africa Big Five: a hunter must kill an African lion, an African elephant, an African leopard, an African rhino and an African buffalo,

- Bears of the World: a hunter must kill four of eleven types of bears,

- Cats of the World: a hunter has to kill four of seven types of cats,

- Spiral-horned Animals of Africa: a hunter has to kill 17 different types of animals,

- "Inner Circle" awards recognize various hunting achievements, such as killing animals with a handgun,

- killing animals on each continent and getting the most entries into the SCI record book.

- To win the highest SCl award, known as "World Hunter of the Year," a hunter must kill more than 300 animals across the globe (Humane Society, 2016).

Less expert trophy hunting activities exist around the globe, one example includes tourists blowing up cows with a rocket launcher in Phnom Penh, Cambodia, or as Baulch (2013) explains:

"Enjoy hunting but aren't particularly good at it? Maybe you suffer from the yips, have an astigmatism, or grew up in Massachusetts and are scared of guns -- not a problem. Upon arrival, customers are presented with an extensive menu of weapons from which to choose, ranging from AK-47s and long rifles to handguns, grenades, and rocket launchers. Clearly, there's no need to worry about accuracy here. Also on the menu? The targets. Maybe you prefer to warm up on something small, like a chicken. That'll be $\$ 100$ if you opt for the machine gun. On a budget? Then best to roll with the pistol: it's only \$15. The "special of the day" every day is a $B-40$ rocket launcher plus cow combo for $\$ 400$. That's $\$ 200$ for the pleasure of shooting a rocket launcher, and $\$ 200$ for the cost of the cow.

Does this constitute sport? Amateur sport hunting? Where do the lines start and end? This is not a debate that will take place here (see Coakley \& Pike, 2009) as people will hold different cultural attitudes, thus, consensus is unlikely. However, there is importance to considering such activities in modern society. The experience economy was a vision set out by Pine and Gilmore (1998). A vision that considered an economic market were consumers searched for affective memories and long-lasting experiences. Or as Schmitt (1999) suggested, consumers wanted experiences that would 'dazzle their senses', 'engage them personally', 'touch their hearts' and 'stimulate their minds'. Or, as noted by Holbrook and Hirschman (1982) consumers want to indulge in experiences that allow them to connect with feelings of fun and fantasy. The point raised here is what role could a vision like the experience economy play in fuelling (sporthunting tourist) consumers desires to seek new experiences? Again, where do the lines start and end, what is acceptable to one culture might not be to another, so tourists will seek locations in which they can satisfy their desires. As long as there is a demand for hunting, then something needs to be hunted.

Sport hunting and tourism are central to this research, and as noted, as an activity, hunting animals has been a common sport and leisure activity, potentially since the dawn of man, and often a pastime that has been associated with noble aristocrats and elite members of society, such as kings and warriors. This is significant, as it is this group, that Wright (2016) suggest will be involved with the hunting human activities in 2100 , and thus, a view that is explored in this research.

\section{Future scenario: Hunting Humans as a sport tourism activity}

As noted, scenario planning often presents a narrative that helps the reader envisage the potential future, which is now presented. Following this is an exploration of current trends, exploring environmental and social patterns and changes, offering evidence from various 
research and knowledge disciplines, as justification to the potential scenario becoming a reality.

The year, 2100.

I have been in the sport hunting business for many years. I started out hunting in the early years of my childhood back in early 2050s. My family lived and owned a large farm. Many people lived in urban areas, but my family decided to take a more rural approach to living. We decided to be more self-sustainable, it was cheaper than living in the densely populated cities - not so luxurious, but it worked for us. We operated well and supported the local community, skills and resources were equally distributed and people made every effort to support each other. We had animals on the farm, cows, chickens, pigs, horses and more. These animals were key to my family's wellbeing and a key income generator. However, there were many wild animals that would come and try and eat our livestock, especially in the dark of night. So I used to stand guard, and shoot to kill, foxes mainly. My pleasure and passion for shooting stated at an early age. As I grew up I decided I wanted to join the forces, so I did. Plus, there was not much for me to do, I couldn't move to the city, I had no money. No skills, not any that would benefit the technologically advanced society that exists. Driven by status, power, money and consumer possessions, a world ruled by corporate banking and consumerist ideologies. I was just a farm girl, what did I know about operating and working in the big city, so of to the army I went. At least they offered the opportunity to travel and see parts of the world that I could only every dream of vising.

Throughout my years as a solider I was involved in many wars. Shooting at animals on the farm is one thing, taking the life of another person, that's something very different, but it was my job, my responsibility, I was a solider of war and was ready to defend myself, my fellow soldiers, to defend my nation. I killed many people during my time in the army, so many, that if possible, it eventually felt normal. I can still remember the first man's life that I took, I can see his eyes staring back at me, desperate, he knew his time was up. With the forces I also travelled a lot and in my spare time off duty, I took many small vacations around the world, made easier by the fact that I moved around a lot, so I could take short trips to nearby countries. Hunting has always been a big part of my life, I did it since I was a young girl on the farm, and for so many years as a profession, so I often sought holiday experiences that involved engaging with guns and other killing machines. One holiday, saw me travel to Cambodia where I blew up a cow with a rocket launcher. Another time I was in Africa and I went on a two-week hunt for wild lions. The thrill and excitement just grew for hunting bigger game, game that was harder to catch - it provided me with such a thrill. I would show off to my friends, when coming together after not seeing each other for some time, we would share the trophies we had collected - often in the form of photos, me standing next to my prize, when possible, I might have even been able to bring back a more tangible token.

However, as the years passed, we lived many wars and society changed somewhat. The environment suffered greatly over the years, and significantly animal populations suffered greatly due to global warming, and due to global population size, we went from around 7 billion to 11 billion between 2050 and 2100 - that's a lot of mouths to feed, and still the majority of the population around the world were starving. As the environment changed, land became uninhabitable, and large sections of the world and its people were forgotten about. The urban populations in the large cities were hypocritical in the early stages... everyone was determined that we had to help everyone in the world, whilst continuing to live expansive, lavish, luxury, consumeristic lifestyle. However, when millions of refugees started to swarm across the oceans in desperation... putting massive stress on service and resources in the more arable lands, residents gradually became less welcoming. It was easy manageable, they closed the boarders, the news stopped reporting what was going on in the wider world, people in the big cities no longer had the capability to understand and do anything about it. It was easier to forget and move on, at the end of the day so many other countries were doing the same. Human nature sufficed and being safe, keeping your family safe was all that mattered, luck of 
the passport I guess, being born in a safe environment was the best chance you had... otherwise you were left to what eventually became referred to as the 'outerworld or the 'outerlands', the world beyond the walls of the mega cities. What happened there, well, resources depletion. Government armies would do what they could to strip lands and oceans of their resources, to continue and maintain the peace within the cities, as people still wanted to shop, to eat, to enjoy life. As a member of the forces, I spent a lot of my time in the outerlands. There are were a lot of desperate people living in those territories, territories that had become rather complex environments to operate in, and therefore, a lot of ground warfare took place and a lot of other dark and nasty practices, it wasn't a safe place to be and the people were violent.

I have hunted the largest game, hunting is in my blood, death has been forever part of my life. Society made it feel morally unacceptable to hunt and kill animals, especially with the limited numbers left in the wild, genetically modified animals was discussed, but was never seen as a solution to solve the severe loss. One day I was offered this sport-tourism opportunity by some military friends. You had to be invited to get involved, it was still a somewhat murky topic, some say the, 'last taboo', it was a vacation to go and hunt humans. I was told that there was nothing illegal about it, especially because it was a practice that was mainly been carried out by elite and wealthy individuals. After all, this is a form of sport-tourism that was only allowed by individuals, who had money or knew the right people.

So, in today's world, a human catch is the ultimate catch; it's the ultimate sport-hunting trophy, and I wanted one, plus it cost me a lot of money. But the thrill and excitement is like no other, far removed from my days as a young girl hunting on the farm.

\section{Future Society}

From here on in, the article will offer exploration and justification of trends that are potentially driving the future scenario. As noted above by Larson (2002: 7), negative scenarios, ones that may present themselves as dystopian to us, are arguably easier to express because researchers find it more simplistic to offer future realities based on current trends, such as population growth and resource depletion; all of which will lead to an inevitable crisis. Difficult or simplistic does not need to be the issue of debate in this case. What is necessary is to consider expert views on population growth as greater numbers of people are living on planet earth. With it, based on current patterns, greater levels of consumptions (natural environment) are likely, putting great strain of natural resources. Thus, there is a correlation between resource depletion and population growth and significantly the potential result on our social and environmental outlooks, therefore, the character and essence of future societies will be different as a result.

For the future scenario to take place, the future of society will not be as we know it today. With variable realities facing the future of society and a potentially volatile global environment, it is not surprising that authors and researchers have recognised the potential of what would seem to us as dark or dystopian futures. To clarify, a dystopia future relates or denotes an "imagined place or state in which everything is unpleasant or bad, typically a totalitarian or environmentally degraded one" (Oxford Dictionaries, 2017b). Limited resources will lead to restricted allocations, and this strain on society will be ever more significant in a world with a growing population (in this scenario said to be around 11 billion by 2100). This figure was recognised by a report published in the journal Science. Gerland et al, (2014) note that this century is unlikely to see a stabilization in world population growth and that by 2100 global population will likely be between 9.6 to 12.3 billion. Also highlighting that fast growth in population could lead to higher levels and distribution of pollution, greater scarcity of resources and increased levels of unemployment, poverty, crime and political unrest. 


\title{
7. Reduction in animals to hunt: Hunting animals to hunting humans
}

\author{
Unless we act now, \\ wildlife populations will decline by $67 \%$ by 2020 \\ (Living Planet Report, 2016)
}

"For the first time since the demise of the dinosaurs 65 million years ago, we face a global mass extinction of wildlife. We ignore the decline of other species at our peril - for they are the barometer that reveals our impact on the world that sustains us. Humanity's misuse of natural resources is threatening habitats, pushing irreplaceable species to the brink and threatening the stability of our climate" (Barrett, 2016).

A report published by WWF and ZSL (Zoological Society of London, 2016) highlights the fragile landscape of natural environments. The report also highlights how food production to meet the needs of an expanding human population is a key driver of activities such as, overfishing, hunting and destruction of habitats, all of which are causing biodiversity loss. According to director General of WWF international, Marco Lambertini, "Across land, freshwater and the oceans, human activities are forcing species populations and natural systems to the edge. We have the tools to fix this problem and we need to start using them if we are serious about our own survival and prosperity." Furthermore, Professor Ken Norris, Director of Science at ZSL added that, "If half the animals died in London zoo next week it would be front page news," But that is happening in the great outdoors. This damage is not inevitable but a consequence of the way we choose to live" (Carrington, 2014). Norris stressed that nature, which provides food and clean water and air, was essential for human wellbeing.

"Human behaviour continues to drive the decline of wildlife populations globally, with particular impact on freshwater habitats. Importantly, however, these are declines - they are not yet extinctions - and this should be a wake-up call to marshal efforts to promote the recovery of these populations" (Norris, 2016).

International scientists endorsed that humanity's impact on the Earth has become so profound that a new geological epoch - the Anthropocene - should be declared. In the UK, the RSPB's State of Nature (2016) report shows that over the last 50 years, 56 per cent of native species have declined (Living Planet Report, 2016). The Living Planet Report (2016) is not alone in stressing the decline in animal population globally. A paper published in Science Advances by Ceballos, Ehrlich, Barnosky, Garcia, Pringle \& Palmer (2015), the researchers stress, somewhat contrary to Norris (2016) above, that Earth is (emphasis added) beginning to enter a new extinction phase - the sixth mass extinction in Earths journey. Lead author, Ceballos, stressed that if humans did not act now, in the next 50 years we will be living in a completely different world, an experience that has never been lived by humanity. It is stressed, this is a result of growing evidence that there is increased depletion in large number of species globally (also considered by Wright, 2016). A research published in the journal Science suggests that we should be concerned of modern ocean acidification, with the research highlighting that a continued neglect of our oceans would threaten the entire marine biosphere as well as landdwelling creatures who are ocean dependent (Merchant, 2015). Clearly, there is an issue, a seriously concerning one. The author could have drawn on a range of examples of specific / individual species that are threatened by extinction, but if researchers are suggesting that we are entering a sixth mass extinction, one would think that this would be enough to sound the alarm bells, so to say. All of this is seen as highly significant in terms of a shift in global consciousness, at least at a hunting level; especially if humans are to be the next on the hunters trophy list. 


\subsection{A shift in global consciousness: negative attitudes towards hunting animals}

"Saving the great parks and wildernesses of Africa is becoming part of African national pride. Botswana must be proud that they have the largest remaining elephant population on earth. As South Africans we must be proud to have the largest rhino population in the world. Rwanda must be proud of the mountain gorilla. Tanzania proud of the largest lion population anywhere" (Boyes, 2013).

Recent years have seen some substantial developments and changes in attitudes towards animal hunting activities. Mitigating the negative effects of hunting around the world for food motives is of great importance (Petroman, Petroman and Marin, 2015), and studies and policies aim to explore innovations to establish and promote alternative food and income sources, particularly for rural populations (Milner-Gulland, Bennett, and the SCB, 2003; Nasi et al., 2008). However, and significantly, researchers suggest that alternative "motivations for hunting are rarely considered in resolving the impacts of this activity" (El Bizri, Morcatty, Lima, and Valsecchi, 2015: 2). In direct relation to discussions in this research, sport hunting, is an example considered. It is noted that sport hunting can extensively contribute to the decline of game species' populations and this is especially noticeable when not properly regulated. It is communally accepted that the most socially acceptable type of sport hunting in the world is hunting that is focused on and aims to manage (animal) populations of introduced or native species undergoing uncontrolled population growth in various environments (Henderson, Warren, Newman, Bowker, Cromwell, and Jackson, 2000).

There are many reports and research studies across continents that have explored the impact of hunting on animal populations and social-cultural concerns. Yasuda (2012) portrays a case of insufficient public management in relation to sport hunting in Cameroon; Weber, GarcíaMarmolejo and Reyna-Hurtado (2006) explored hunting programs in Mexico and suggests that there are severe impacts on wildlife populations; identifying a lack of knowledge and an incapacity to maintaining proper infrastructure, personal training, and sustainability assessments. In a study by Loveridge et al. (2006) they identify the impacts of trophy hunting in the United States on the behaviour of wild animals, their report suggests that the animals' natural movement patterns in Yellowstone National Park are significantly affected by hunting activities. According to Pérez and Ojasti (1996) countries in South America keep protectionist policies in relation to sport hunting to reduce and even attempt to banish the activity.

In line with the reports of declining animal numbers globally and extinction possibilities, it is no surprise that stories of tourists hunting animals have become 'media juice' for journalists and reporters of late - a great opportunity to shame hunters in a world where apparent global awareness and consciousness of our impacts on the environment is mounting. A recent article offered the following: "Tourists hide their faces in shame before shooting dead hoards of animals in 'barbaric' hunt in South Africa" (Dubuis, 2015). The article notes how tourist where left hiding their faces in shame as they embarked on a 'barbaric' hunt in the South African province of Limpopo. The hunt, denounced as a "canned massacre" by conservationists, saw 20 Belgian and Dutch (tourist) hunters taking part in a week-long event. Photos depicted 'chasers' who were lined along a 1.2 mile stretch of land where they herded baboons, warthogs, antelopes, amongst other wild animals out of the dense bush and into a clear and open space. It is here the sport hunting tourists awaited, stationed on raised wooden platforms offering an easy aim at the animals as they passed - reports suggested nearly 60 animals had been killed within the first three days (Dubuis, 2015).

The earlier example was the killing of Cecil the lion, a national treasure to the Hwange National Park, western Zimbabwe. According to Zimbabwean officials Dr. Walter Palmer (dentist), an American hunter, killed Cecil (Rogers, 2015). Images of the hunter with the lion soon went viral across the internet and Walter Palmer soon became a 'hated' man, or at least that is what the media had us believe. With newspaper headlines like the following soon emerging, "Dentist 
who killed Cecil has become the most hated man on the Internet" (Steinbuch, 2015); "Cecil the lion's killer, Walter Palmer, has slayed a range of animals - and is now most hated hunter in America" (Pratt, Slattery \& Mcshane, 2015); and "Why The Internet Hate For Walter Palmer Matters" (Woosley, 2015). And it is Woosley (2015) that highlights the point also been made in this research, by suggesting the following:

"The public outcry against the killing of Cecil has been relentless, and for good reason. We are tired of seeing pictures across social media of young girls, middle-aged men and everything in between posing with their latest hunting trophy. We are heartbroken that lions, tigers, rhinos, elephants and so many endangered species are being mercilessly killed in the name of sport. In many ancient cultures, animals were revered. The people would kill animals to use for meat, clothing and tools, but they would often have a ceremony to thank them and celebrate them for their sacrifice. This kind of hunting and killing wild endangered animals as a sport to wear as a badge of honor feels selfish and senseless".

There is a growing sentiment that our animal habitants are precious, and that the hunting of wild, endangered or not, animals for sport and as a touristic activity, and or for monetary gain for communities is an immorally and selfless act. As noted in the above scenario, the hunting of animals will potentially, gradually decline, as animal numbers significantly decrease and growing anger and hostility is poured on the individuals who take part, by society, and fuelled by media coverage, be it national media or social media. In time, and in line with the illustrated future being presented in this research, as a result in seismic shifts and decline in our natural environment, increased population sizes, closed off nations and city-states, society in the future, in 2100 , will be significantly different. It is within this society that Wright (2016) eluded to a world in which the wealthy-elite would carry out human hunting activities for entertainment. For this to take place, this research argues, that 'sport hunting' and 'sport tourism' will be a key contributor driving the future. Significantly, the elite aristocrats, the upper echelons of societies, who just like the past and today are more likely to partake in hunting activities, could be responsible for the progression of hunting animals to hunting humans.

\subsection{A history of hunting humans}

The idea of hunting humans is commonly associated as a theme in fiction, as noted earlier. However, the act of killing humans is not limited to fiction. Recently, a report by Hotfelder (2009) highlights how Russian yachts offered pirate hunting of the Somali Coast. The report suggested that Russian yacht owners were offering hunting vacations to shoot Somali pirates. Violence and killing other humans has long been part of human nature, and whilst the origins of such killing nature are debated, as are the origins of war, there are signs that such behaviours are deeply rooted in evolution (Gorman, 2016). A recent report in the journal Nature provides insights into potentially some of the earliest signs of inter-group violence, in West Turkana, Kenya (about 10,000 years ago), between early Holocene hunter-gatherers. Scientists uncovered 12 skeletons, 10 of which showed evidence of having died violently at the edge of a lagoon, into which some of the bodies fell (Mirazón Lahr et al., 2016). Hedges (2003) suggested that war took the lives of at least 108 million people throughout the twentieth century. As for the total number of people killed in wars throughout all of human history estimates range from 150 million to 1 billion. "As long as Man continues to be the ruthless destroyer of lower living beings, he will never know health or peace. For as long as men massacre animals, they will kill each other" Pythagoras.

There have been historical incidents of the practice being carried out during times of social upheaval (Hochschild, 2016). Historically, society has shown its desire to hunt, as Gasset (1972: 31) suggests: "The aristocrat has always done the same things: raced horses or 
competed in physical exercises, gathered at parties, the feature of which is usually dancing, and engaged conversation. But before any of those, and consistently more important than all of them has been... hunting... This is what kings and nobles have preferred to do: they have hunted".

The life of a man in industrialized countries is not that of the natural man - man "...is still an animal formed for battle and conquest, for blows and strokes and swiftness, for triumph and applause" (Brill, 1929, 434). Brill (1929) goes on to identify that man can attain personal excitement and situation from sport spectatorship. Theorists have suggested that individuals fail to receive sufficient levels of stimulation in their everyday lives (see Elias \& Dunning. 1970; Howard, 1912; Klapp; 1972; Klausner, 1968; McNeil, 1968; Zuckerman, 1984). Due to this, people seek out alternative opportunities to gain stimulation and excitement. Paintball could be used as an example, a competitive team shooting sport where enemy players eliminate each other by shooting (using an air-weapon) dye-filled gelatine capsules (Lone Wolf Paintball, 2019). The game originated in the early 80 's as a form of recreation but is now played at a sporting level through organised competitions and tournaments by professional teams and players (Paintballing, 2019; Super 7s Paintball, 2019). The concept of eustress, is often associated with sport fandom (Gantz, 1981; Gantz \& Wenner, 1995; Sloan, 1989; Smith, 1988), and embodies the idea that participation in sport fandom (spectatorship) can offer excitement and stimulation for individuals (Wann et al., 2001). The notion of eustress as a stress and stimulation seeking theory is associated with how direct and indirect sport consumption can result in positive and negative stress and distress capabilities. Here it is suggested that the need for stimulation and excitement from everyday life through the motives commonly associated with eustress - seeking direct sport consumption, (participating not just spectating) could be a guiding factor to elitist societies, hunting humans for sport in the future. In line with this article, the participant above, suggested to be ex-military would welcome a stress releasing sport, with a recent report identifying them as having an occupation with the highest level of stress (Dill, 2016). Could hunting humans be a continued religious act of authority or in the future, for sport could it be a manifestation of historical religious acts of human sacrifice? Either way, as noted in an in the journal Nature (Watts et al., 2016) the sacrificial or killing of humans was a pastime of elitist societies in the past and occurred in Germanic, Arab, Turk, Inuit, American, Austronesian, African, Chinese and Japanese cultures (Carrasco, 1999; Turner \& Turner, 1999). Social control hypotheses note that human sacrifice legitimised class based power distinctions by combining displays of ultimate authority, the taking of life, using supernatural justifications, sanctifying authority as divinely ordained.

In Wright's (2016) paper the author suggests that the elitist in society will be the hunters, and the impoverished of society will be the victims. Historically, hunting for sport could be an act more associated with aristocrats, today however, the sport hunting is more widely present across different societal groups, and the less well off in society can also engage in sport hunting activities. So it could be suggested, unlike the idea posed in Wright's (2016) paper the elite could just as well be the victims. Alternatively, could people offer themselves up to be hunted. Hickey (2011) discuss a website Hunt me 4 sport (2011). One the site a man called Mork Encino offers himself to be hunted. The spiel includes the following:

"I seek hearty gents who fancy themselves sportsmen and bored of the usual game. I am a new breed of prey with thick pelt and smooth hide. I'm faster than a wild turkey, smart as any GODDAMN wild boar and willing to make the ultimate sacrifice for the monetary health of my family. If I am trapped and killed you stand to earn the RESPECT of your fellow hunters, a PRIZE HUMAN MOUNT for your wall and ALL INCOME from any organ harvest. For this I ask the reasonable sum of $\$ 10,000$ US DOLLARS per hunter/per round. I will be armed only with my wits and the clothes on my back (naked is $+\$ 2,000$ US/per hunter/per round). A round is a days (24 hrs) hunt. I will not attempt self-defense. I will only seek to evade capture. In the event of my demise ALL payment will default to my family" (Hickey, 2011). 
This clearly is not a current trend, but the idea that people are or even could offer themselves as victims of human sport hunting raises many concerns. Especially, if survival is deemed lucrative and extra cash benefits are available through sporting spectatorship. One does not need to look far back in history to remember when death and spectatorship were common within the public domain - Roman gladiatorial games being one such example. As stated by Malcom X, "education is the passport to the future, for tomorrow belongs to those who prepare for it today". How are we preparing and educating society today to ensure history does not repeat itself in the future?

\section{Creating better futures}

It is stressed that the future scenario presented is proposed to be a manifestation of current trends and developments in society. In a previous paper where Wright (2016) explored the potential for hunting humans in the year 2200 for tourism, driven by entertainment, in this case the focus is on sport in a hunting context. Whist the previous publication by Wright (2016) grabbed the tabloid media's attention, much of the focus was on the future scenario and as a headline seizing opportunity.

Hunting HUMANS set to become big business for the super rich within next 100 years, (Mirror, 2016).

Could Hunger Games become a reality? Hunting HUMANS may be a hobby for the rich in the next 100 years, (MailOnline, 2016).

Would YOU hunt HUMANS? Chilling holiday activity is just around the corner, says expert, Romeo (2016) in the Express.

In tourism, as a collective body (from researchers to industry) we have a strong position to attract attention, because tourism is a leisure activity, and a pastime that many people around the world have, in some form or another partaken in. Thus, a large portion of our global society at some stage has been a tourist, therefore, making it easier to engage and have an opinion. So, such dystopian future scenarios have the potential to incite interest from readers. This future scenario and potential reality has been created by exploring current trends. Therefore, it is revealing to consider, that, what we are creating and establishing today will be inherited by future generations.

Science fiction, movies and entertainment industries commonly portray and present artistry images, words and visual expressions of what a dystopian future might resemble. The Encyclopedia of Science Fiction notes that dystopian works depict a negative view of "the way the world is supposedly going in order to provide urgent propaganda for a change in direction" (Stableford, 1993). Literary examples of dystopia include the $19^{\text {th }}$ Century novel, The Republic of the Future: or, Socialism a Reality by American writer Anna Bowman Dodd, first published in 1887; the Unknown Tomorrow (1910) by William Le Queux; The City of the Living Dead (1930) by Laurence Manning and Fletcher Pratt; A Clockwork Orange (1962) by Anthony Burgess; The Running Man (1982) by Stephen King under the pseudonym Richard Bachman. The Sound of His Horn (1952), another dystopian novel, here the author explores the future around the notion of 'alternative history', envisaging a world where the Nazis won World War Two. In a fantasy alternative narrative approach, writer John William Wall (written under the pseudonym Sarban) portrays the idea of a generally being time travelled to a future around 100 years post-war. In this future, there exists artificially created being, such as baboonheaded boys. Human hunting is a vivid reality in this fantasy future narrative (Nicholls, 1983). In reviewing the book, Shimmin (2019) notes the following, "The Sound of His Horn is a very 
odd book indeed with its hybrid creatures, Nazis, feudal lords, and unexplained time travel. Sarban tells it though in a calm, matter of fact and very English tone that tends to undermine the more fantastic elements and make it seem almost real." Movies and entertainment industries have inundated their audiences with a mixture of dystopian futures, such as The Book of Eli, a 2010 American post-apocalyptic neo-Western and action film directed by the Hughes brothers, written by Gary Whitta; Mad Max, a 1979 Australian dystopian action film directed by George Miller, produced by Byron Kennedy; The Hunger Games movies directed by Austrian-born American film director, producer Francis Lawrence. Recently TV series such as The Walking Dead, an American horror drama television series developed by Frank Darabont, based on the comic book series of the same name by Robert Kirkman, Tony Moore, and Charlie Adlard; Black Mirror, a British science fiction television series by Charlie Brooker, which canters on dark and satirical themes that explore society, particularly with regard to the unexpected impacts of new technologies. More closely related to the subject of sport and dystopian futures are Rollerball, a 1975 British-American dystopian science fiction sports action film, produced and directed by Norman Jewison, the movie envisages a future society that uses an ultra-violent game as entertainment; Death Race 2000 (1975 / 2008), a 1975 cult political satire action film directed by Paul Bartel. The film takes place in a dystopian American society in the year 2000, where the murderous Transcontinental Road Race has become a form of national entertainment, a car race in which inmates must brutalize and kill one another on the road to victory. The Most Dangerous Game 1924, a short story by Richard Connell features a big-game hunter from New York City, when falling of his yacht, swims to an isolated island in the Caribbean where he is then hunted by a Russian aristocrat, and Future Sports 2002 edited by Jack Dann and Gardner Dozois offering future worlds of weird sportsmanship in a unique sci-fi anthology of short stories; in this case, less emphasis on death. Contrary to previous research and or short stories, this paper offers further evidence and data based on current trends to justify a scenario for sport hunting as a tourism experience in the future.

Industries have often explored the future and also reflect on potential dystopian and crisis stricken realities, such as The World in 2050, a future study presented by Frank Appel, CEO Deutsche Post DHL, offering five scenarios entitled: 1) Untamed Economy - Impending Collapse, 2) Mega-Efficiency in Megacities, 3) Customized Lifestyles, 4) Global Resilience and 5) Paralyzing Protectionism. The later more similar to this research, presenting a gloomy picture of the future for 2050, where nationalism dominates, reimposed boarders, trade restrictions, mutual mistrust, greater stagnation and conflict of natural resources are a daily occurrence; a future that is more inclined to past ways of living (Appel, 2012). For further academic research and scenarios that paint a dark view of the world see Hall (2013), entitled Through a glass darkly: The future of tourism is personal (in Leigh, Webster \& Ivanov, 2013) and Wright (2016) Hunting humans: A future for tourism in 2200. The future will arguably be different and a myriad number of depictions of dystopian views have been offered across disciplines. Thus, whilst it might seem complex, or outlandish to make such a claim, the potential reality (in this research, hunting humans for sport as tourism recreation) should be contemplated. Larson (2004: 5) provides this resonating point:

"Yet another uncertainty is that predictions themselves can alter the future-which, of course, is part of the motivation behind futurism."

The examples provided above are but a small selection of the vast and diverse mix of dystopian stories, be it fiction or nonfiction material, all of which have been shared with a plethora of global audiences. So the question, are these depictions and stories of dystopian futures driving, modifying, creating our future? According to previous research potentially so (Wright, 2016). We have the ability to create the future. This notion of our role in creating the future is significant and well documented by James Ogilvy (2002) in his book Creating Better 
Futures. When considering advances throughout our world, Ogilvy (2002) notes that society is changing, and significantly, we should seek to change it for the better. Thus, if we can influence the future for the better, it is necessary to have an idea of where we are heading, and thus what can we change? Ogilvy (2002) suggests that scenario planning is not a tool for making better predictions, as the future is irregular, more than ever so. Instead, scenario planning should be used as a tool for better decision making. The test of a good scenario is not down to the accuracy of predicting the future - more importantly, the measure of a good scenario should be based on weather society, those with an interest, made better decisions as a result of having considered the scenario (Ogilvy, 2002). So, the reader is left with this question, what role do we have in creating the future scenario, are we comfortable with it and what can we do now to ensure, that if we are not, how can we create a different world, a different future, one that does not resemble a dystopian reality to us, one where hunting humans is not a reality?

\section{Conclusion}

This research paper set out to explore the future of tourism from a sport-hunting context. More specifically, it can be seen as a prequel to a paper by Wright (2016) in which he suggests that in the future, hunting humans will form part of the tourism entertainment industry. Wright (2016) offered a brief insight into what the future might look like in the year 2100 before focusing his narrative, his future scenario in the year 2200. This paper took the thematic basis that, if hunting humans were to become a sport-tourism based activity of the future, then sporthunting, along with other current trends, would have a significant role in driving such a reality. Trends considered, where the diminishing level of animal populations globally and the growing animosity towards sport-hunting as a pastime activity often undertaken by aristocrats and elite members of society. Additionally, the influence of repeated productions of dystopian futures displayed across various artistic mediums, especially movies, TV and fictional narratives, and significantly, how these could inadvertently create the futures they are portraying. An area that has not been explored in detail in this research is the role of the sport fan, and that of sport fandom. Previous sport tourism research has examined how sports fans are entertained by violent conduct (Bryant, 1989; Bryant, Comisky \& Zillmann, 1981; Bryant \& Zillmann, 1983; Kaelin, 1968). The phrase, "violence sells" is not new, and in producing violent programming media powers are said to be delivering what the public, spectators' desire (Wann etal., 2001); just as rulers did during the Roman Gladiatorial games. Further research in the field of sport tourism with a futures approach could continue to explore the role of violent behaviour in spectators - what does a future of fans thirsty for violence look like?

This paper is not presenting a sensationalist representation of the future. The aim is not the presentation of a narrative, a story with the intention to provoke public interest at the expense of accuracy. Whilst this paper could potentially be seen as provocative, the aim of the research was to establish and justify a scenario that offers readers with 'interesting research', one that leads to debate, contemplation, and critique. Presenting ideas that encourage readers to reconsider normal patterns of thinking, in order to question our current behaviours, with the intention to strive for arguably better futures. It does so by exploring historical and current patterns and trends in society to provide valid justifications for the scenario. The researcher is 'shining a light' on a difficult subject area. It is an academic endeavour and responsibility to explore difficult topics in research. Further research should consider how such dystopian societies can be avoided, what measures need to be taken, what changes and options are available to humanity to ensure society does not steer itself towards such a future. Further research should also consider alternative dystopian futures, as warning signals of what could lie ahead. Such research could consider developments in technology, in which human-animal hybrids or even human cloning and or genetically modified humans could become a reality, and potentially form part of a future hunting activity / market for tourists. Optimistically, as 
individuals and part of collectives in society, we have the potential to influence the future; we have the ability to create better futures. And it is with this final message that the reader should depart with, are we aware of all the subcultures that exist in society, are we comfortable with how other subcultures conduct and behave, and if not, what do we as a society do about it? What we do now echoes in eternity - Marcus Aurelius. Our actions have the potential to resonate throughout eternity, which of our actions do we want future societies to inherit? 


\section{References}

Alvesson, M., \& Sandberg, J. (2011). Generating research questions through problematization. Academy of Management Review, 36(2), 247-271.

Appel, F. (2012). The World in 2050 - Future study presented by Frank Appel, Online video by Deutsche Post DHL Group, Available at:

https://www.youtube.com/watch?v=VEOIPTfsBol. Accessed on: 23/01/2017.

Bale, J. (1989). Sports Geography. London: E. and FN Spon.

Barrett, M. (2016). Living Planet Report 2016, Available at:

https://www.wwf.org.uk/updates/landmark-report-shows-global-wildlife-populations-coursedecline-67-cent-2020. Accessed on: 20/01/2017.

Bartunek, J. M., Rynes, S. L., \& Ireland, R. D. (2006). What makes management research interesting, and why does it matter? Academy of management editors' forum. Academy of Management Journal, 46(1), 9-15.

Batchelor, T. (2015). PICTURED: Queen and Prince Philip pose with dead tiger 50 years before Cecil the lion. Available at: http://www.express.co.uk/news/royal/595424/QueenPrince-Philip-pose-dead-tiger-50-years-before-Cecil-lion-controversy. Accessed on: 23/11/2016.

Boyes, S. (2013). No Trophy hunting in Botswana and Zambia. Available at: http://voices.nationalgeographic.com/2013/01/22/no-trophy-hunting-in-botswana-andzambia/. Accessed on: 20/01/2017.

Brill, A. A. (1929). The why of the fan. North American Review, 228; 429-434.

Bryant, J. (1989). Viewers' enjoyment of televised sports violence. In Wenner, L. A. (eds) Media, sports and society, Newbury Park, CA: Sage, pp. 270-289.

Bryant, J., Comisky, P. W. \& Zillmann, D. (1981).The appeak of rough-and-tumble play in televised professional football. Communication Quarterly, 29, 256-262.

Bryant, J. \& Zillmann, D. (1983). Sport violence and the media. In Goldstein, J. H. (eds), Sports violence, New York, Springer-Verlag, pp. 195-211.

Carrasco, D. (1999). City of Sacrifice: The Aztec Empire and the Role of Violence in Civilization, Boston, Beacon Press.

Carrington, D. (2014). Earth has lost half of its wildlife in the past 40 years, says WWF. Available at: https://www.theguardian.com/environment/2014/sep/29/earth-lost-50-wildlife-in40-years-wwf. Accessed on: 20/01/2017.

Cartwright, G. (2005). The Thrill of the Hunt. Texas Monthly, March: p. 88-92.

Ceballos, C., Ehrlich, P. R., Barnosky, A. D., Garcia, A., Pringle R. M., \& Palmer T. M. (2015). Accelerated modern human-induced species losses: entering the sixth mass extinction. Science Advances 1-5.

Chermack, T. J., Lynham, S. A. \& Ruona, W. E. A. (2001). A review of scenario planning literature. Futures Research Quarterly, 17(2), 7-32. 
Chermack, T. J. (2011). Scenario planning in organizations: how to create, use and assess scenarios. San Francisco: Berrett-Koehler Publishers.

Coakley, J. \& Pike, E. (2009) Sport in Society: Issues and Controversies, McGraw-Hill Education, Berkshire.

De Bono, E. (1995). Serious Creativity: Using the Power of Lateral Thinking to Create New Ideas. New York, Harper Collins Business.

Dill, K (2016). The 10 most stressful jobs in 2016. Available at:

http://www.forbes.com/sites/kathryndill/2016/01/11/the-10-most-stressful-jobs-in2016/\#724f20d74b54. Accessed on: 15/02/2017.

Dubuis, A. (2015). Tourists hide their faces in shame before shooting dead hoards of animals in 'barbaric' hunt in South Africa. Available at: http://www.mirror.co.uk/news/worldnews/tourists-hide-faces-shame-before-6464344. Accessed on: 18/01/2017.

Dunning, E. (1986). Sport as a Male Preserve: Notes on the Social Sources of Masculine Identity and its Transformations. Theory, Culture \& Society, 3(1), 79-90.

Dunning, E. (1999). Sport Matters: Sociological Studies of Sport, Violence and Civilization. New York: Routledge.

Elias, N. \& Dunning, E. (1970). The quest for excitement in unexciting societies. In Luschen, G. (eds), The Cross-cultural analysis of sport and games. Champaign, IL; Stipes.

Elias, N. \& Dunning, E., (1986). Quest for Excitement: Sport and Leisure in the Civilizing Process, Blackwell, Oxford.

Encyclopedia Britannica (2017). Hunting and gathering culture; ANTHROPOLOGY, Available at: https://www.britannica.com/topic/hunting-and-gathering-culture. Accessed on: 18/01/2017.

Fa, J. E., \& Garcia Yuste. J. E. (2001). Commercial bushmeat hunting in the Monte Mitra forests, Equatorial Guinea: extent and impact. Animal Biodiversity and Conservation, 24(1), 31-52.

Fowler, J. \& Rodd, E. (2017). The Future is Uncertain. It's Time to Start Asking the Right Questions. Available at: http://bigthink.com/big-think-tv/the-future-is-uncertain-its-time-tostart-asking-the-right-questions. Accessed on: 13/02/2017.

Friedman, G. (2009). The Next 100 years: a forecast for the $21^{\text {st }}$ Century. Anchor Books, Random House, New York.

Gammon, S. (2015). Sport tourism Finding its Place? In Gammon, S. \& Elkington, S. (eds) Landscapes of Leisure: Space, Place and Identities, Routledge, Hampshire, pp. 111-122.

Gammon, S. \& Robinson, T. (1997). Sport and Tourism: A Conceptual Framework, Journal of Sport Tourism, 4(3), 8-24.

Gantz, W. (1981). An exploration of viewing motives and behaviors associated with television sports. Journal of Broadcasting, 25; 263-275.

Gantz, W. \& Wenner, L. A. (1995). Fanship and the television sports viewing experience. Sociology of Sport Journal, 12; 306-323. 
Gasset, J. O. Y-. (1972). Meditations on Hunting, trans. Wescott, H. B. New York, Wilderness Adventuress Press.

Gaudzinski, S. (2004). Subsistence patterns of Early Pleistocene hominids in the Levant Taphonomic evidence from the 'Ubeidiya Formation (Israel). Journal of Archaeological Science. 3. 65-75.

Gerland, P., Raftery, A. E., Ševčíková, H., Li, N., Gu, D., Spoorenberg, T., Alkema, L., Fosdick, B. K., Chunn, J., Lalic, N., Bay, G., Buettner, T., Heilig, G. K., \& Wilmoth, J. (2014). World population stabilization unlikely this century. Science, 346(6206), 234-237.

Gibson, H. (1998). Active Sport Tourism: Who Participates? Leisure Studies, 17(2), 45-76.

Gibson, H. (2006). Sport Tourism: Concept sand Theories. An Introduction. In Gibson, H. (eds) Sport Tourism: Concepts and Theories. Sport in the Global Society series, Oxon Routledge: 1-9.

Godet, M., \& Roubelat, F., (1996). Creating the future: the use and misuse of scenario planning. Long Rage Plan, 29(2), 164-171.

Godet, M. (2000). The art of scenarios and strategic planning: tools and pitfalls.

Technological Forecasting and Social Change, 65(1), 3-22.

Gorman, J. (2016). Prehistoric Massacre Hints at War Among Hunter-Gatherers. Available at: https://www.nytimes.com/2016/01/21/science/prehistoric-massacre-ancient-humans-laketurkana-kenya.html. Accessed on: 25.01.2019.

Hall, C. (1992). Adventure sport and health tourism, in Weiler, B. and Hall, C. M. (eds) Special Interest Tourism. London, Bellhaven Press; 141-158.

Han, D.-H. (2011). Scenario construction and its implications for international relations. The Korean Journal on International Studies, 9(1), 39-65.

Hedges, C. (2003). 'What Every Person Should Know About War'. Available at: https://www.nytimes.com/2003/07/06/books/chapters/what-every-person-should-knowabout-war.html. Accessed on: 25.01.2019.

Heijden Van der., Bradfield, R., Burt, G., Cairns, G., \& Wright, G. (2002). The sixth sense: accelerating organizational learning with scenarios. Chichester, UK: Wiley.

Henricks, T. S. (1991). Disputed Pleasures: Sport and society in preindustrial England. Westport, CT. Greenwood Press.

Hickey, B. (2011). If You've Always Wanted To Hunt a Live Human, Here's Your Willing Prey. Available at: https://deadspin.com/if-youve-always-wanted-to-hunt-a-live-human-heresyour-5815424. Accessed on: 25.01.2019.

Hinch, T. \& Higham, J. (2001). Sport Tourism: A Framework for Research. The International Journal of Tourism Research, 3(1), pp. 45-58.

Hinch, T. \& Higham, J. (2011). Sport Tourism Development (Second Edition). Bristol, Channel view Publications. 
Hochschild, A. (2016). Spain in Our Hearts. New York, Houghton Mifflin Harcourt.

Holbrook, M. B. and Hirschman, E. (1982). "The Experiential Aspects of Consumption: Consumer Fantasies, Feelings and Fun", Journal of Consumer Research, 9(2), 132-140.

Hotfelder, A. (2009). Russian yachts to offer "pirate hunting" cruises off Somali coast. Available at: http://gadling.com/2009/06/29/russian-yachts-to-offer-pirate-hunting-cruises-offsomali-coas/. Accessed on: 23/01/2017.

Howard, G. E. 91912). Social psychology of the spectator. American Journal of Society, 18; 33-50.

Humane Society (2016). Trophy Hunting by the Numbers: the united states' role in global trophy hunting. Available at:

http://www.hsi.org/assets/pdfs/report_trophy_hunting_by_the.pdf. Accessed on: 23/01/2017.

Hunt me 4 sport (2011). This Here is Mr. Encino. Available at:

http://huntme4sport.com/post/10692910774/this-here-is-mr-encino. Accessed on:

25.01.2019.

Jacobs, J. M. (2015). The Future of Sports. Available at: http://futureof.org/wpcontent/uploads/The-Future-of-Sports-2015-Report.pdf. Accessed on: 23/01/2017.

Jones, I. \& Green, B. (2006). Serious Leisure, Social Identity and Sport Tourism. In Gibson, H. (eds). Sport Tourism Concepts and Theories, Sport in the Global Society series, Oxon, Routledge: 32-49.

Kaelin, E. F. (1968). The well-played game: Notes toward an aesthetics of sport. Quest, 10, 16-28.

Klapp, O. E. (1972). Currents of unrest: An introduction to collective behaviour. New York: Holt, Rinehart \& Winston.

Klausner, S. Z. (1968). The intermingling of pain and pleasure. The stress-seeking personality in its social context. In Klausner, S. Z. (Eds) Why man takes chances. Garden City, NY, Doubleday/Anchor, pp137-168.

Kurtzman, J. (1995). Sports Tourism Categories revisited. Journal of Sport Tourism, 2(3), pp. $1-11$.

Larson, R. W. (2002). Globalization, Societal Change, and New Technologies: What They Mean for the Future of Adolescence, Journal of Research on Adolescence, 12(1), 1-30.

Leigh, J., Webster, C., \& Ivanov, S. (2013). Future Tourism: political, social and economic challenges (advances in tourism). Oxon, Routledge.

Lindgren, M., \& Bandhold, H. (2009). Scenario planning: the link between future and strategy. New York: Palgrave Macmillan.

Lindsay, R. (2009). Modern Hunter-Gatherers in Africa and Elsewhere, Available at: https://robertlindsay.wordpress.com/2009/06/08/modern-hunter-gatherers-in-africa-andelsewhere/. Accessed on: 18/01/2017. 
Living Planet Report (2016). Living Planet Report 2016: Risk and resilience in a new era. Available at:

http://www.wwf.org.uk/sites/default/files/201610/LPR_2016_full\%20report_spread\%20low\%2 Ores.pdf. Accessed on: 20/01/2017.

Lone Wolf Paintball (2019). Safety \& Rule Games. Available at:

http://www.lonewolfpaintball.com/safety/. Accessed on: 25.01.2019.

Loveridge, A. K., Reynolds, J. C. \& Milner-Gulland, E. J. (2006). Does sport hunting benefit conservation? Pages 224-239 in D. Macdonald, and K. Service, editors. Key topics in conservation biology. Blackwell, Oxford, UK.

Machiavelli, N. (1531). Discourses on the first decade of Titus Livius, Book 3. In Gilbert, A. (1989). Machiavelli: The Chief Works and Others. 1. Duke University Press p. 419-532.

MailOnline (2016). Could Hunger Games become a reality? Hunting HUMANS may be a hobby for the rich in the next 100 years. Available at:

http://www.dailymail.co.uk/sciencetech/article-3654200/Are-enter-Hunger-Games-HuntingHUMANS-hobby-rich-100-years.html. Accessed on: 26/01/2017.

Manning R. B. (1993). Hunters and Poachers: A cultural and social history of unlawful hunting in England 1485-1640. Oxford, Oxrofd University Press.

McNeill, M. (1996). Netwroks: Producing Olympic ice hockey for a national television audience. Sociology of Sport Journal, 13; 103-124.

Merchant, B. (2015). The last time oceans go this acidic this fast, $96 \%$ of marine life went extinct. Available at: http://motherboard.vice.com/read/the-last-time-our-oceans-got-thisacidic-it-drove-earths-greatest-extinction. Accessed on: 20/01/2017.

Mirazón Lahr, M., Rivera, F., Power, R. K., Mounier, A., Copsey, B., Crivellaro, F., Edung, J. E., Maillo Fernandez, J. M., Kiarie, C., Lawrence, J., Leakey, A., Mbua, E., Miller, H., Muigai, A., Mukhongo, D. M., Van Baelen, A., Wood, R., Schwenninger, J.-L., Grün, R., Achyuthan, H., Wilshaw, A., \& Foley R. A. (2016). Inter-group violence among early Holocene hunter-gatherers of West Turkana, Kenya. Nature, 529, pages394-398

Mirror (2016). Hunting HUMANS set to become big business for the super rich within next 100 years. Available at: http://www.mirror.co.uk/news/weird-news/hunting-humans-setbecome-big-8244649. Accessed on: 26/01/2017.

Nasi, R., Taber, A., \& van Vliet, N. (2011). Empty forests, empty stomachs? Bushmeat and livelihoods in the Congo and Amazon Basins. International Forestry Review, 13(3), 355-368.

Nasi, R., D., Brown, D., Wilkie, E., Bennett, C., Tutin, G. van Tol., \& Christophersen, T. (2008). Conservation and use of wildlife- based resources: the bushmeat crisis. CBD Technical Series Number 33. Secretariat of the Convention on Biological Diversity, Montréal, Québec, Canada, and Center for International Forestry Research, Bogor, Indonesia.

Available at: http://www.cbd.int/doc/publications/cbd-ts-33-en.pdf Accessed: 23/11/2017

Nicholls P. (1983). "The Sound of His Horn", in Magill, F. N. (eds), Survey of Modern Fantasy Literature, Vol 4. Englewood Cliffs, NJ: Salem Press, pp. 1789. 
Nogawa, H., Yamagucji, Y., \& Hagi, Y. (1996). An Empirical Research Study on Japanese Sport Tourism in sport-for-all events. Case Studies of a Single-Night Event and a MultipleNight Event. Journal of Tourism Research, 35(2), pp. 46-54.

Norris, K. (2016). Living Planet Report 2016, Available at:

https://www.wwf.org.uk/updates/landmark-report-shows-global-wildlife-populations-coursedecline-67-cent-2020. Accessed on: 20/01/2017.

Ogilvy, J. A. (2002). Creating Better Futures: Scenario planning as a tool for a better tomorrow. New York, Oxford University Press.

Oxford Dictionaries (2017a). Hunt. Available at:

https://en.oxforddictionaries.com/definition/hunt. Accessed on 18/01/2017

Oxford Dictionaries (2017b). Dystopia. Available at:

https://en.oxforddictionaries.com/definition/dystopia. Accessed on: 23/01/2017.

Paintballing (2019). So you want to become a professional paintball player huh? Available at: https://www.paintballing.co.uk/paintballing-blog/so-you-want-become-professionalpaintball-player-huh. Accessed on: 25.01.2019.

Peterson, G. D., Cumming, G. S., \& Carpenter, S. R. (2003). Scenario planning: a toll for conservation in an uncertain world. Conservation Biology, 17(2), 358-366

Petit-Dutaillis, C. (1914). Studies an Notes Supplementary to Stubbs' Constitutional History, trans Waugh, W. T. 3 vols (Manchester).

Petroman, I., Petroman, C., \& Marin, D. (2015). Place of Hunting Tourism in the Structure of Modern Tourism Types. Animal Science and Biotechnologies. 48(2), 199-202.

Pine, B. J. II. \& Gilmore, J. H. (1998). "Welcome to the Experience Economy", Harvard Business Review, 76(4): 96-105.

Postma, A. (2015). "Investigating scenario planning? A European tourism perspective". Journal of Tourism Futures, 1(1), 46-52.

Pratt, A., Slattery, D., \& Mcshane, L. (2015). Cecil the lion's killer, Walter Palmer, has slayed a range of animals - and is now most hated hunter in America. Available at: http://www.nydailynews.com/news/national/cecil-lion-killer-part-elite-hunting-group-article1.2307692. Accessed on: 20/01/2017.

Rabinovich, R., Gaudzinski-Windheuser, S., \& Goren-Inbar, N. (2008). Systematic butchering of fallow deer (Dama) at the early Middle Pleistocene Acheulian site of Gesher Benot Ya'aqov (Israel), Journal of Human Evolution. 54. 134-149.

Ramirez, R., Mukherjee, M., Vezzoli, S., \& Kramer, A. M. (2015). Scenarios as a scholarly methodology to produce "interesting research". Futures, 71, 70-87

Ravera, F., Hubacek, K., Reed, M., \& Tarrason, D. (2011). Learning from experiences in adaptive action research: a critical comparison of two case studies applying participatory scenario development and modelling approaches. Environmental Policy and Governance, $21,433-453$.

Redford, K. H. (1992). The empty forest. BioScience 42(6), 412-422. 
Ringland, G. (2006). Scenario planning-managing for the future. Chichester: John Wiley and Sons.

Redmond, G. (1991). Changing styles of sports tourism: Industry/Consumer Interactions in Canada, the USA and Europe. In Sinclair, M. and Stabler, M. (eds) The Tourism industry: An International Analysis. Wallingford: CAB International; pp.107-120.

Rogers, K. (2015). American Hunter Killed Cecil, Beloved Lion Who Was Lured Out of His Sanctuary. Available at: https://www.nytimes.com/2015/07/29/world/africa/american-hunteris-accused-of-killing-cecil-a-beloved-lion-in-zimbabwe.html?_r=0. Accessed on: 20/01/2017.

Romeo, K. (2016). Would YOU hunt HUMANS? Chilling holiday activity is just around the corner, says expert. Available at: http://www.express.co.uk/travel/articles/682161/huntinghumans-holiday-pastime-expert-tourism-prediction-author-author: Accessed on: 26/01/2017.

Rooney, J. F. \& Pillsbury, R. (1992). Sports regions of America. American Demographics, 14(10), 1-10.

Roxburgh, C. (2009). The use and abuse of scenarios. McKinsey Quarterly 1-10.

Sankaran, S., Dick, B., Shaw, K., \& Cartwright, C. (2014). Application of scenario-based approaches in leadership research: an action research intervention as three sets of interlinked practices. Systemic Practice and Action Research, 27(1), 105-573.

Schmitt, B. (1999). Experiential Marketing, New York: The Free Press.

Schwartz, P. (1991). The art of the long view: Planning for the future in an uncertain world. New York, Doubleday.

SCI (2016). Hunter Advocacy. Available at: https://www.safariclub.org/what-we-do/freedomto-hunt. Accessed on: 20/01/2017.

Shimmin, G. (2019). The Sound of His Horn - Book Review. Available at: http://graemeshimmin.com/the-sound-of-his-horn-book-book-review/. Accessed on: 29.03.2019.

Sloan, L. R. (1989). The motives of sports fans. Goldstein, J. D. (eds) Sports, games, and play: Social and psychosocial viewpoints ( $2^{\text {nd }}$ ed). Hillsdale, HJ: Lawrence Erlbaum Associates, pp. 175-240.

Smith, G. J. (1998). The noble sports fan. Journal of Sport \& Social Issues, 12. 54-65.

Stableford, B. (1993). "Dystopias". In Clute, John; Nicholls, Peter. The Encyclopedia of Science Fiction (2nd ed.). Orbit, London. pp. 360-362.

Standeven, J. \& De Knop, P. (1999). Sport Tourism. Champaign, IL, Human Kinetics.

Steinbuch, Y. (2015). Dentist who killed Cecil has become the most hated man on the Internet. Available at: http://nypost.com/2015/07/29/guides-who-helped-kill-cecil-facepoaching-charges/. Accessed on: 20/01/2017.

Super 7s Paintball (2019). Super 7s Tournament Paintball. Available at: http://super7spaintball.com/. Accessed on: 25.01.2019.

The Oxford English Dictionary (2015). Futurology. Available at: 
https://en.oxforddictionaries.com/definition/futurology. Accessed on: 12/01/2017.

Turner, C. G., \& Turner, J. A. (1999). Man Corn: Cannibalism and Violence in the Prehistoric American Southwest, Utah, University of Utah press.

Van der Heijden K. (2005). Scenarios: the art of strategic conversation, second ed. Chichester: Wiley.

Wann, D. L., Melnick, M. J., Russell, G. W., \& Pease, D. G. (2001). Sport fans: The psychology and social impact of spectators. New York, Routledge.

Watts, J., Sheehan, O., Atkinson, Q. D., Bulbulia, J., \& Gray, R. D. (2016). Ritual human sacrifice promoted and sustained the evolution of stratified societies. Nature, 532; 228-234.

Weed, M. (2008). Sports Tourism: A Reader. Oxon, Routledge.

Weed, M., \& Bull, C. (1999). Sports tourism: Participants policy and providers. Oxford, Butterworth-Heinemann.

Wilkins, K. (2013). The year of ancient ghosts. Greenwood, WA: Ticonderoga Publications.

Woosley, M. (2015). Why The Internet Hate For Walter Palmer Matters. Available at: http://www.huffingtonpost.com/megan-woolsey/walter-palmer-internet_b_7891756.html. Accessed on: 20/01/2017.

Wright, D. W. W. (2016). Hunting humans: A future for tourism in 2200, Futures 78-78. P.3446.

Yeoman, I. (2012). 2050-tomorrow's tourism. Bristol: Channel View Publications.

Yinger, M. (1960). Contraculture and subculture, American Sociological Review, 25(5), 625635.

Zenin, V. N., Mashenko E. N., Leshchinskiy, S. V., Pavlov, A. F., Grootes, P. M. Nadeau, MJ. (2003). The First Direct Evidence of Mammoth Hunting in Asia (Lugovskoye Site, Western Siberia) (L). 3rd International Mammoth Conference. Dawson City.

Zenter, R. D. (1982). Scenarios, past, present and future. Long Range Plan, 15(3), 12-20.

Zuckermann, M. (1984). Sensation seeking: A comparative approach to a human behaviour. The Behavioural and Brain Sciences, 7; 413-471. 